\title{
Multiple Principals' Preferences, Types of Control Mechanisms and Agent's Discretion in Trade Negotiations
}

\author{
Eugénia da Conceição-Heldt \\ $1 \quad$ INTRODUCTION $^{1}$
}

The European Parliament (EP) is now granted joint powers with the Council of the EU on trade policy issues. When it comes to the negotiation of free trade agreements (FTAs), the European Commission (henceforth, the Commission) acts on behalf of multiple principals: the Council and the EP. However, few studies, to my knowledge, examine whether multiple principals and the type of control mechanisms available to principals shape agency discretion. Hitherto, delegation studies on EU trade politics focuses on the Commission's role in global trade negotiations (Conceição-Heldt 2010; Dür and Zimmermann 2007; Elsig and Dupont 2012), on why the involvement of the EP in EU trade policy was long opposed by member states and trade policy experts (Eeckhout 2011; Meunier 2003), and on whether the EP's power has increased with the entry into force of the Treaty of Lisbon (Richardson 2012; Van den Putte et al. 2015; Woolcock 2010). Some studies focus specifically on the discretion of the Commission and show that the preference heterogeneity of the principals with two camps of equal size and a broad negotiating mandate increases the agent's discretion

E. da Conceição-Heldt ( $\square)$

Technical University of Munich, München, Germany

(C) The Author(s) 2017

T. Delreux and J. Adriaensen (eds.), The Principal Agent Model and

the European Union, Palgrave Studies in European Union Politics,

DOI 10.1007/978-3-319-55137-1_9 
(Conceição-Heldt 2011; Elsig 2010). Others show how growing capabilities, preferences and entrepreneurship lead to more emancipation of the agent from principals (Niemann and Huigens 2011). Yet others investigate how agents are able to weaken principals' incentives to control (Delreux and Kerremans 2010; Heldt 2017), how national administrations maintain their capacity to control the agent (Adriaensen 2016), and how internal cohesiveness together with the bargaining context shapes the external effectiveness of the EU in trade negotiations (Conceição-Heldt 2014; Elsig 2013; Niemann and Bretherton 2013). This contribution complements the other chapters assembled in this edited volume, for example Niemann and Plank's study of the conditions under which agents are more likely to acquire more discretion vis-à-vis the principals (Plank and Niemann this volume), Helwig's examination of how agent interaction affects the EU High Representative's level of discretion (Helwig this volume) and Kroll's piece on the Council having different mechanisms of control at its disposal to control the European Council (Kroll this volume). Specifically, I explore how changing a delegation structure that relies on multiple principals shapes the agent's discretion in the negotiation of trade agreements. The concept of discretion refers here to the leeway conferred to an agent to accomplish a delegation mandate. I argue that an agent's amount of discretion can be high or low depending on the preference heterogeneity between multiple principals and the type of control mechanisms available to principals during the negotiation process. In a configuration of preference heterogeneity of multiple principals and formal control mechanisms, the agent's discretion is more likely to increase. In a configuration of preference homogeneity, by contrast, agent's discretion should decrease, as principals are united and thus send a single message to their agent. The dyadic principal-agent relations as well as the main theoretical focus of the chapter are presented in Fig. 1.

This chapter engages specifically with two issues raised in the Introduction (Delreux and Adriaensen this volume). First, it delineates the sources of agent's discretion. Second, it shows specifically how preference heterogeneity between multiple principals, together with control mechanisms, increases or decreases agent's discretion. Based on primary sources from the Commission's Directorate General, press releases and statements from the Trade Policy Committee (TPC) ${ }^{2}$ at the Council and the International Trade Committee (INTA) at the EP, this chapter sheds 


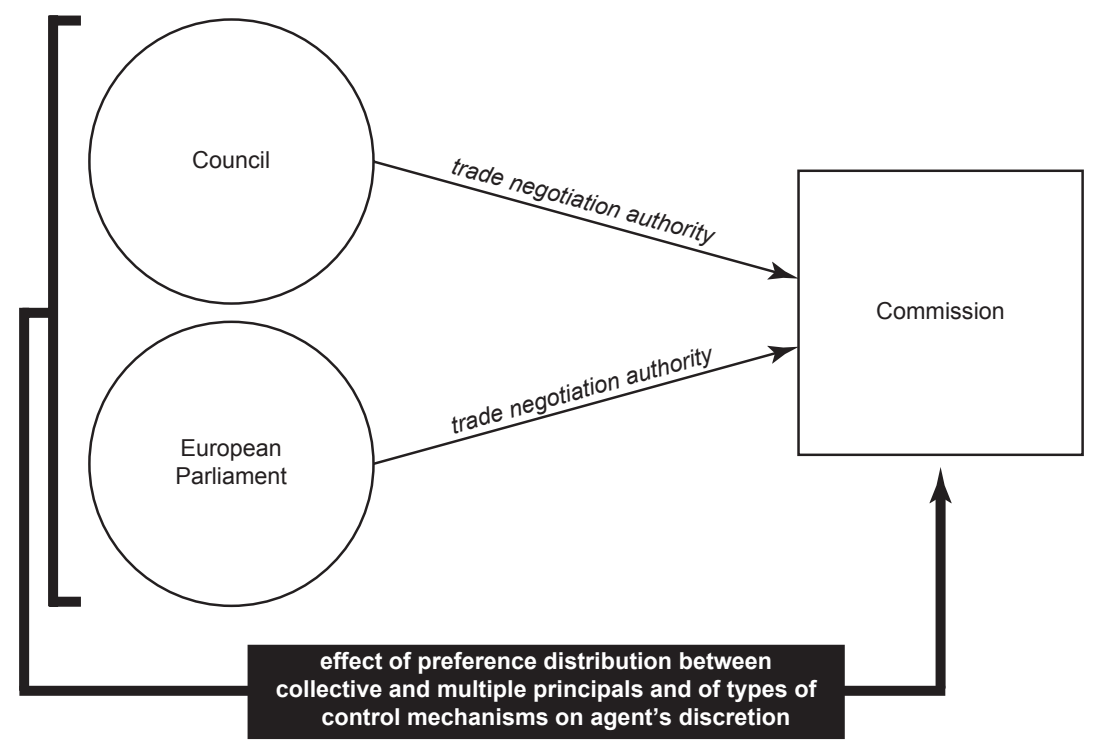

Fig. 1 Visualization of the principal-agent relationship, multiple principals' preferences, types of control mechanisms and agent's discretion

light on the Commission's discretion in complex delegation patterns. To illustrate the argument made, I use a comparative research design and have chosen two case studies of the negotiation of FTAs with variance on the independent variable. The first case with preference heterogeneity of multiple principals focuses on the EU-South Korea FTA. The second case study on the EU-Singapore FTA negotiations illustrates a case of preference homogeneity of multiple principals.

\section{Theoretical Puzzle: Multiple Principals' Preferences and Control Mechanisms}

The politics of delegation in trade policy correspond to a complex delegation game between the agent (the Commission) and multiple principals (Council and EP). Trade policy falls under the exclusive competence of the EU. This means in practice that EU member states in the collective principal, the Council, empowered the Commission to represent 
them and thus to act on their behalf in the negotiation of trade agreements. The term collective principal refers to a corporate entity in which the principal is composed of more than one actor. Since the entry into force of the Treaty of Lisbon in December 2009, the delegation game has changed, as the EP is now granted joint powers with the Council when it comes to the negotiation and ratification of trade agreements. This means that the Commission now acts on behalf of multiple principals. The term multiple principals refers to a delegation situation, in which agents have delegation contracts with more than one principal (Nielson and Tierney 2003). As the editors of this volume underline, the act of delegation itself is a necessary feature to consider an actor as a principal (Delreux and Adriaensen this volume). One could of course argue that because the EP does not delegate power to the Commission, iterated delegation as control mechanism does not apply in this specific institutional constellation. Formally, the EP is not entitled to grant the Commission a negotiating mandate, which remains an exclusive competence of the Council. However, the Commission has to inform the EP on the state of negotiations and report extensively to EP's INTA during the course of negotiations and take EP's preferences into account to avoid involuntary defection at the ratification stage. Accordingly, the Commission is fully aware that insufficient information provision, for example but not giving access to negotiating texts, would bear negative consequences at the ratification stage. Moreover, the EP's routine to adopt a resolution as a surrogate mandate at the start of the negotiations turns it automatically into a principal. This resolution can be considered an informal act of delegation from a principal-agent perspective, as the EP 'briefs' the Commission on the issues which have to be taken into account when negotiating a trade agreement in order to gather support at the ratification stage (on the concept of informal delegation, see Reykers and Beach, this volume). ${ }^{3}$ In this way, the EP is not only a veto player at the ratification stage, but also informally a principal during the negotiations. As the Commission now acts under a new institutional constellation, this raises the question to which extent the heterogeneity or homogeneity of multiple principals' preferences and control mechanisms shape the agent's range of discretion.

What we do know from the delegation literature is that agents necessitate a certain range of discretion to successfully accomplish a delegation mandate. ${ }^{4}$ By now, numerous studies have dealt with an agent's amount of discretionary authority. Carpenter (2001) considers an agent's level of 
discretion to be part of the contractual arrangement between agents and principals. Hawkins et al. (2006b) point out that discretion gives agents a certain room for maneuver in performing the delegated task and taking decisions without interference from principals. The concept of discretion involves a grant of authority that indicates the principals' goals, but does not specify the specific actions agents must take to accomplish their mandates. Thatcher and Stone Sweet (2002) conceive the gap between what principals want from their agents and what agents actually do as the 'zone of discretion'. This zone is constituted by the sum of delegated authority minus the sum of control mechanisms available to principals to shape or annul policy outcomes as a result of agents' performance in fulfilling their tasks. Other scholars emphasize that discretion includes the scope of issues the agent is authorized to handle, the policy instruments it has at its disposal and the procedures it should follow to use those policy instruments (McCubbins et al. 1987). Discretion is seen as a necessary condition for agents' successful accomplishment of their mandates. Epstein and O'Halloran (1999) suggest that the discretion given to agents varies depending on the complexity or uncertainty inherent to a certain issue. They expect principals to give their agents more discretion in technical or complex areas. Whereas Moe (1990) suggests that principals exert managerial control over this discretion, Whitford (2005) demonstrates that in the case of divided government in the USA, the heterogeneity of principals' preferences causes Congress to constrain the agency by delegating less discretion. In a situation of multiple principals (for example, the US president and Congress), attempts by one principal to control the bureaucracy constitute a direct response to another principal's control attempts. I reverse this argument by showing that a constellation involving multiple principals with heterogeneous preferences can increase, rather than decrease, an agent's discretion.

In this chapter, agency discretion is defined as the range of leeway principals give to their agents within a delegation contract. In contrast to previous studies (Hawkins et al. 2006a, Thatcher and Stone Sweet 2002), I treat discretion is a dichotomous variable that can be either high or low. High discretion is given when the level of multiple principals' interference in agent's actions before, during and after negotiations is minimal. By contrast, low discretion characterizes a situation in which the level of multiple principals' interference in agent's actions before, during and after negotiations is extensive. In this chapter, I argue that when the degree of cohesiveness of multiple principals is low (preference 
heterogeneity) and they are thus disunited, agency discretion is more likely to increase. Et ceteris paribus, the more homogenous the preferences of multiple principals, the lower the range of discretion of an agent is expected to be. In terms of increasing the EU's bargaining power, one could of course argue that multiple principals with divergent preferences reduce the win-set, that is to say 'the range of agreements at the international level that are acceptable at the domestic level' (Putnam 1988: 437 ) and thus the room within which the agent can find an acceptable compromise. My argument here, however, is that disunity increases the agent's discretion because the agent can use buffering and permeability strategies to increase its discretion when negotiating a trade agreement.

The amount of agent's discretion varies depending on the preference constellation and the type of control mechanisms available to principals. Discretion is low in a situation of principals' preference homogeneity and when they have extensive formal control mechanisms to monitor their agent before, during and after the negotiations. The first mechanism of control is the delegation mandate, in which principals stipulate the negotiating issues and the general and broad content of a trade agreement. During the course of negotiations, principals' effective control takes place within Council's and EP's trade committees in form of regular oral reporting.

In order to explore the effect of preference heterogeneity and control mechanisms on agency discretion, the next section examines multiple principals' preferences on trade issues and the types of control mechanisms available to principals in the post-delegation stage.

\section{Empirical Analysis: Multiple Principals' Preferences on Trade}

EU member states have different preference intensities when it comes to trade issues. Furthermore, scholars widely agree that interest groups play a central role in explaining the origin of states' trade policy preferences (Dür 2010; Goldstein 2012; Milner 1997; Moravcsik 1997). For example, Frieden (1999) posits that national preferences are determined by sub-national interests, in particular by powerful groups which are able to set national priorities, such as interest groups, parties or bureaucracies. Moravcsik (1993) goes a step further by assuming that the greater the economic benefits for powerful interest groups, the greater their 
incentives are to lobby national government representatives to ensure their preferences are taken into consideration in trade negotiations. By contrast, the costlier the adjustments, the more opposition to a trade agreement will arise. More recently, EU trade policy scholars distinguish between net importers and net exporters, between goods and services traders, and between protectionist and free traders (Dür 2007). In the EU context, however, interest groups do not only try to influence their governments at the national level. In order to be effective, interest groups must simultaneously organize themselves at the European level to make themselves heard at three different levels: national Permanent Representations, Commission and EP. Whether they are able to influence trade agreements depends on their ability to organize and to formulate their preferred policy position and to communicate that position within the context of interest group competition.

Member states trade policy preferences can be protectionist or liberal depending on the economic issues at stake. Liberal preferences refer to a state favoring more trade liberalization for a given economic sector. A protectionist trade preference means that a country wants to keep the status quo by maintaining a high level of protection for a certain economic sector. Consequently, countries can have protectionist positions in one economic sector and liberal ones in another. Depending on the issues at stake, member states' representatives can even opt for a tradeoff between the sectors gaining and losing from a change of the status quo and adapt their trade positions accordingly during the negotiation process.

Assessing member states' preferences on trade agreements is only the first step in explaining the Commission's range of discretion in trade negotiations. In order to fully explain its level of discretion, one also has to assess the general position of the second principal, the EP, on trade agreements. Admittedly, there is an extensive discussion in the literature on whether the empowerment of the EP will lead to a more normative trade policy via the inclusion of social, environmental, human rights and democracy aspects in the negotiation of trade agreements (Krajewski 2013). ${ }^{5}$ As complement to these studies, and similar to the Council, I will assess the EP's trade policy preferences by briefly detailing the position of different political groups on international trade issues. Van den Putte et al. (2015) show that political groups' cohesiveness is stronger on international trade issues than on all other issues. They looked at the votes for specific trade agreements and found that there is 
a left-right division. Left parties, such as the European United Left and the Greens, voted against trade agreements proposed by the Commission as well as the amendments made by the EP. Christian-democrat and Liberal party groups, such as the Group of the European People's Party (EPP), the Alliance of Liberals and Democrats for Europe (ALDE) and the European Conservatives and Reformists (ECR), mostly favor trade agreements and thus more free trade. In general, social-democratic parties, assembled in the Group of the Progressive Alliance of Socialists and Democrats (S\&D) at the EP, are aligned with center-right and Christian democrats. Extreme-right and populist, anti-EU parties, for example, represented in the Europe of Freedom and Direct Democracy (EFDD) Group, have a low cohesiveness on international trade agreements and hitherto have sometimes voted in favor and sometimes against trade agreements (Van den Putte et al. 2015: 11, 22). Similar to the preferences of EU member states, I assume that members of the EP (MEPs) are influenced by societal groups, including sectoral interest groups and NGOs. In this way, their position on trade agreements goes back to the ideological position of a party group and on the ability of societal groups to formulate policy demands and to make themselves heard within the EP's committees.

Agency discretion is not only a function of principals' preferences, but also of the types of control mechanisms stipulated in the delegation contract. Control mechanisms are the institutional constraints within which each agent acts on behalf of principals. The principal-agent literature shows that principals try to minimize agency losses, which are inherent to the delegation relationship, by using different types of control mechanisms, including the contract design, monitoring and reporting requirements, institutional checks, and even sanctioning (Hawkins et al. 2006a; Pollack 2003). When analyzing the complex delegation relationship in trade, I focus on three types of control mechanisms: before (ex ante), during and after the negotiations (ex post). ${ }^{6}$ Ex ante mechanisms refer to the design of the delegation mandate before the beginning of negotiations. During the course of negotiations, monitoring takes place at the Council's and EP's committee levels. Finally, ex post mechanisms are anchored in the ratification process.

Ex ante control mechanisms are laid out in the contract between principals and agents. This contract determines the scope of the agent's authority, the instruments the agent can use to fulfill its task and the procedures agents should follow in employing those instruments 
(McCubbins and Page 1987). In general, the delegation mandate of the Commission at this stage is vague. Principals state what their preferences are and issues that should be included, but they leave it to the Commission to figure out how to fulfill the assigned mission. The Council empowers the Commission to speak on their behalf in the negotiation of trade agreements. However, before the agent can act on behalf of the collective principal, the latter has to give the Commission for each single negotiation a negotiating mandate. This mandate is prepared by the Commission and then presented to the Council, which has then to be approved by qualified majority by the Council. A negotiating mandate comprises general guidelines that specify principals' objectives, in this case, a successful conclusion of negotiations, as well as principals' priorities regarding the degree of concessions the agent is allowed to make on various issues. However, these directives leave it to the agent's discretion to choose specific negotiating strategies for reaching an agreement.

It is only in the course of negotiations that principals interfere more or less depending on whether their preferences converge (low discretion of the agent) or diverge (high discretion of the agent). As the EP is not empowered to co-draft and approve the Commission's mandate for the negotiations, the Commission can decide the extent to which she informs the EP on the exact content of the mandate and on the state of negotiations. With the signature of the inter-institutional agreement between the Commission and the EP, the first provides the same information to the Council and the EP during the negotiation process (Conceição-Heldt 2016). At this post-delegation stage, informal consultation with the EP is important as it helps avoid involuntary defection ex post at the ratification stage. During the negotiations, control mechanisms, which refer to the monitoring and reporting requirements available to principals giving them detailed information about the agent's actions, come into play. In this context, different types of control mechanisms, police patrol and fire alarm (McCubbins and Schwartz 1984), have an impact on an agent's range of discretion. Police patrol control mechanisms refer to legal rules and formal texts in which it is stipulated that an agent is monitored actively and directly by the principals with the aim of constraining agency discretion. Such instruments might include regular reporting in committees, questioning representatives from European institutions, the preparation of reports, or even direct field observations, where principals participate in negotiations. By contrast, fire alarm control mechanisms, in analogy to concerned citizens alerting 
firefighters about dangerous activities (Lupia 2003), require less direct intervention by principals, who instead rely on third parties. This type of control mechanism allows principals to externalize the costs of monitoring to third parties, including citizens, interest groups, courts, national parliaments, or new agents. This has the advantage of allowing principals to gather information at a lower cost. In addition, in a well-designed fire alarm system, third parties bring agents' violations of mandates to the principals' attention (Kiewiet and McCubbins 1991).

In the specific case of EU trade governance, after the Council has delegated power and defined the negotiating mandate of the Commission, the latter is formally and closely monitored by member states at the ministerial and committee levels during the negotiations. At the ministerial level, the Commission reports twice a year to the FAC. At the trade committee level, the Commission now reports on a regular basis not only to the $\mathrm{TPC}^{7}$ at the Council, but also to the INTA at the EP. These centralized police patrol mechanisms allow principals to control their agent during the negotiation stage and, if necessary, signal agents as to where the red lines are. By having the Commission report regularly on the state of negotiations, principals can alter the agent's discretion by enabling or constraining certain courses of action. The central question is whether the strengthening of police patrol mechanisms, together with the degree of cohesiveness between multiple principals, increases or decreases the Commission's range of discretion in trade negotiations.

After the conclusion of negotiations, ex post control mechanisms are used at the ratification stage. If principals decide not to ratify an agreement, ex post control functions as a sanction mechanism. All trade agreements have to be ratified by the EP and the 28 member states. When principals consider that an agent has overstepped its negotiating mandate, ex post control mechanisms give principals the power to reverse an agreement, for example by refusing to ratify an agreement negotiated by the agent. Sanctions are a further instrument principals can use in case they are dissatisfied with an agent's performance. Sanctions might include budget cuts, dismiss personnel, or strengthening control mechanisms by creating an additional new committee to monitor the activities of an agent (for a discussion of sanction mechanisms, see Hawkins et al. 2006b; Heldt 2017).

The following sections illustrate the argument made by focusing on two case studies: the EU-South Korea and the EU-Singapore FTA negotiations. While the first case study stands for a situation of heterogeneity 
of multiple principals' preferences, the second case study corresponds to a situation of homogeneity of multiple principals' preferences. In the studied cases, the institutional context, and thus the formal control mechanisms, remained the same during the course of negotiations.

\subsection{EU-South Kovea FTA: Preference Heterogeneity of Multiple Principals}

Negotiations on a FTA with South Korea began in May 2007, and the agreement was signed in April 2011 and entered into force in July 2011 (Directorate General for External Policies 2009). The main issues at stake for the EU were to obtain better access to the South Korean market for its automobile, pharmaceutical, cosmetic and chemical products as well as for its services sector. The South Korean government, in turn, asked for better market access for its automobile, electronic and textile sectors (Agence Europe 2007).

From the very beginning, the European automobile sector, represented in the peak association European Automobile Manufacturer's Association (ACEA), and the textiles sector, represented in the European Textile Federation (Euratex), opposed the FTA, as they would be the main losers of a change of the status quo (Agence Europe 2009c). These two sectors asked for a system of import surveillance and the use of duty drawback safeguard mechanisms. Duty drawback refers to the tariff rates paid on parts and components used for the production of a final product which are refunded when that final product is exported. The communications and financial and banking services sectors, by contrast, would be the sectors winning the most from an FTA agreement (Directorate General for External Policies 2009). Even though member states had divergent preferences on the FTA, they were able to speak with a single voice toward the Commission. Those countries with a protectionist position regarding automobiles and textiles including Germany, the Czech Republic, France, Hungary, Italy, Poland, Portugal, Slovakia and Spain asked for protection of their automobiles and textiles sectors. In contrast, countries with a liberal trade preference toward services, such as the United Kingdom and Sweden, pleaded for a swift conclusion of the trade agreement as they expected their services sector to gain most from an FTA with Korea (Agence Europe 2009b).

During the negotiations, the EP was particularly concerned with the inclusion of a duty drawback clause in the FTA. In line with the 
protectionist position of the automobile and textile sectors, the EP asked for the inclusion of a safeguard clause for these two sectors (Van den Putte et al. 2015). This would allow the EU to impose safeguard measures, if lower customs duties led to a major rise in imports from South Korea. In addition, the EP wanted close supervision of the implementation of the FTA with Korea via the establishment of a Trade Committee complete with an efficient dispute settlement mechanism (Agence Europe 2010). This newly established Advisory Trade Committee is composed of representatives from the European Commission and the South Korean government (European Commission 2010). In addition to the member states, the Commission and the EP, interest groups representing more than 25 percent of the industry are also entitled to open an investigation in the EU-South Korea advisory trade committee, if they consider that safeguard measures are necessary (Agence Europe 2010). By contrast, the Commission considered that the duty drawback clause would have a minimal impact on these two sectors and opposed accordingly the introduction of this special safeguard clause using the argument that it would give South Korea significant market advantages over European industries due to its strong cost-competitive advantage over European small car manufacturers (Committee on International Trade: European Parliament 2010).

Aware of the low degree of cohesiveness between the Council and the Parliament, the Commission used buffering and permeability strategies to increase its range of discretion during the negotiations. As we know from organizational sociology, agents can resist monitoring, which DiMaggio and Powell (1991) call buffering, through ceremonialism. This refers to an agent's strategy in which the information and reporting provided by the agent attempt to satisfy principals without revealing too much information (Hawkins and Jacoby 2006). One way of doing this is to induce principals to accept incomplete information or even to make monitoring informal and superficial. By contrast, permeability refers to agents giving informal access to third parties (Tallberg et al. 2013) and thus allowing them to participate in the decision-making process. Opening up access to third-parties allows agents to increase their discretion as they can use the information provided by third parties to increase their power vis-à-vis their principals.

Even though the Commission reported regularly to the TPC and INTA, it used a buffering strategy by reporting only very superficially on the state of negotiations in order to increase its discretion. At a Council 
meeting in July 2009, several member states asked the Commission to specify the effects of the South Korean duty drawback clause. The Commission's negotiators did not provide any substantive response to this request and even held information back by only reporting very broadly on the state and details of the negotiations with the South Korean government. For example, the Commission only made the full 1000 pages of the FTA text available to the TPC and the INTA at the last minute (Agence Europe 2009a).

At the same time, in order to increase its discretion, the Commission used permeability strategies with selected interest groups. The Commission sent questionnaires to business interest groups, such as BusinessEurope, that supported the FTA and to the automobile industry, which did not, in order to obtain more information about their positions related to the FTA. During the negotiation process, the Commission made strategic use of that information by keeping member states, MEPs and business interest groups' representatives informed in a very general way about the process and selectively giving them access to specific parts of the trade agreement text (Elsig and Dupont 2012).

At the end, with the aim of bringing negotiations successfully to an end and to reconcile differences in a manner that suited the dissenting preferences between multiple principals, the Commission integrated the EP's demands on the inclusion of a special safeguard mechanism for the automobile and textiles sectors into the draft agreement in order to avoid involuntary defection at the ratification stage. When it came to the ratification of the EU-South Korea FTA, the EP was highly cohesive. Of a total of 612 MEPs, over 465 voted in favor, 128 against and only 19 abstained. An absolute majority of over 80 percent across left, socialdemocratic and center-leaning Christian democrats and liberal group parties supported the agreement (Votewatch Europe 2014). At the same time, the Commission also included the demands by member states with a more protectionist position on the automobile sector, such as Germany and Italy, by creating new 'product categories' that differentiated between the cars where Italy expected competition (small cars) from those where German exports could easily withstand competition (large upscale and luxury cars).

This case study illustrates that a great preference heterogeneity between multiple principals allowed the agent to enjoy a high level of discretion during the negotiations. The Commission reported regularly to TPC and INTA on the state of negotiations but was able to make use 
of its discretion by using buffering strategies in form of holding information back on the negotiating text and by using permeability strategies with selected economic interest groups to increase its discretion, as the agent was aware of the preference heterogeneity between multiple principals.

\subsection{EU-Singapore FTA: Preference Homogeneity of Multiple Principals}

After the failure to negotiate bloc-to-bloc with ASEAN countries, the EU started negotiations with Singapore in May 2007 and these were concluded in October 2014 (European Commission Department of Trade 2015). ${ }^{8}$ The EU-Singapore FTA corresponds to a configuration in which the Council and the EP were highly united resulting in a low discretion of the Commission. There was a broad agreement within the Council and Parliament that the agreement was a gain for everyone across policy issues from financial services to agricultural and automobile sectors. Since the trade exchange relations between the EU and Singapore, in which about 8000 European businesses are present, are tight, the agreement gives EU agricultural, agribusiness, automobile, business and services sector access to a dynamic market. Member states, EP and the Commission unanimously agreed that Singapore, then largest economy of the Southeast Asian block, was a gateway for the European business sector and could be a catalyst for economic growth for EU exporters. This was particularly important, as the negotiation and conclusion of the FTA occurred during the euro crisis period. Singapore accepted major EU demands on the recognition of EU standards on import of manufactured cars and on agricultural products. This included the protection of geographical designations of origin, which includes Bordeaux wines or Parma ham. In order to take the preferences of the EP into account, the agreement also includes a chapter on sustainable development with the aim of stimulating trade and investment in environmental technologies and renewable energies. At the same time, tariff rates on environmental goods will be upon the entry into force of the agreement immediately abolished (Agence Europe 2012). These issues were particularly relevant for green and leftist groups within the EP. By taking their preferences into account, it is more likely that also a majority of MEPs from these parties will vote in favor of the agreement. 
Altogether, the EU-Singapore FTA provides major gains for the services sector, in particular insurance, banking and financial services. As Singapore does not have an agricultural sector and an automobile industry, gains for all European economic sectors are high. Accordingly, member states with a more protectionist position on these two issues could very easily accept the agreement, as the EU did not have a key sector to be defended.

In a situation of high cohesiveness and preference homogeneity between multiple principals, the agent's discretion was low in this particular case. Member states and MEPs were united and sent a single message to their agent, which then asked the third party to accept a chapter on sustainable development and environmental standards. Under a situation of high preference cohesiveness, the EU's effectiveness was increased and the agent's discretion decreased. There are of course alternative explanations to this result, such as the asymmetrical bargaining power of the third party or the lack of an economic sector with clear defined losers.

\section{Theoretical Argument}

This contribution explored the theoretical puzzle of how changing the delegation structure of an agent acting on behalf of a collective principal (here, the Council of the EU) to an institutional configuration of multiple principals (here, both the Council of the EU and the EP) affected the Commission's range of discretion in the negotiation of trade agreements. I have argued that the agent's degree of discretion varies depending on the degree of unity between multiple principals and on the types of control mechanisms available. Disunity between multiple principals is more likely to increase the agent's discretion in trade negotiations. Under such a configuration, the agent can use buffering and permeability strategies to increase its discretion.

This chapter is a first step toward mapping causal mechanisms that lead to more or less agent discretion at the negotiation stage. On the theoretical side, this piece investigates how agents' discretion is shaped by internal factors. On the one hand, if discretion is shaped by control mechanisms and results from the principal-agent institutional structure, it refers to the concept of agency slippage (Pollack 1997). On the other hand, discretion can be driven by preference divergence between the agent and the principals and references the concept of 
agency shirking (Conceição-Heldt 2010). This contribution enriches this discussion by linking two aspects of the institutional structurepreference heterogeneity between multiple principals and types of control mechanisms - to explain high and low levels of agent's discretion. At a more general level, this contribution demonstrates the limitations of the principal-agent model, with its focus on the formal act of delegation. Formally, the Council of the EU gives the Commission a negotiating mandate. According to the Treaty of Lisbon, the EP only comes into play at the ratification stage. In practice, however, this does not hold. The fact that the Parliament adopts a resolution as a surrogate mandate at the beginning of negotiations turns it into a principal already at this stage. This has a huge impact on trade negotiations, as the EP is able to make itself heard at this stage and the Commission is, of course, willing to take these new demands into account to avoid an EP veto at the ratification stage. Similar to the contribution by Coremans and Kerremans (this volume), this chapter shows that agents are central managers of information asymmetry and to a certain extent able to conceal information from their principals. Whether this situation has changed as a result of the Commission's recent decision in the framework of TTIP negotiations to disclose negotiating texts remains to be explored.

Finally, together with the Introduction (Delreux and Adriaensen this volume), this piece further conceptualizes discretion by distinguishing between low and high discretion. It also shows how thin the line between discretion, autonomy and agency slack might be in complex delegation relations. Agents need discretion and autonomy to successfully accomplish their negotiating mandates. A high level of discretion can also increase agents' autonomy, which refers to agents' ability to successfully pursue their agendas (Tallberg 2000). Thus, autonomy can lead to agency slack, which has always a negative connotation and refers to independent actions undertaken by the agent undesired by principals (Conceição-Heldt 2013). The need to find a right balance between control by principals and agent's discretion to fulfil their mandates without extrapolating toward slack remains a crucial issue in principal-agent relationships (Heldt 2017). Some recent studies draw our attention toward agency slack in the EU and US trade politics (Conceição-Heldt 2013), toward international organizations more generally (Hawkins et al. 2006a) and toward the difficulty in regaining control of errant agents after slack has occurred (Heldt 2017). 
On the empirical side, I analyze two case studies in this chapter which allow me to unpack causal mechanisms (preference heterogeneity between multiple principals and types of control mechanisms) explaining the conditions under which the agent's discretion is high or low. Specifically, the case studies on the EU-South Korea and EU-Singapore FTAs with their focus on the preferences of multiple principals, the interaction between principals and the agent, and different types of control mechanisms enrich our knowledge of principal-agent relationships and illustrate the complexity of these relationships.

\section{Conclusion}

This chapter illustrates that preference heterogeneity between multiple principals increases agency discretion. During the negotiations with South Korea, the Commission was aware of preference divergence between its principals. This allowed the Commission to report only superficially to the TPC and INTA on the state of negotiations and to withhold information on the FTA text until the ratification stage. In this way, it was able to increase its discretion during the negotiation process. In the case of the EU-Singapore FTA negotiations, by contrast, preference homogeneity decreased agency discretion. Multiple principals' preferences converged and they were thus united, reducing the Commission's discretion during the negotiation process. A primary observable implication of my argument is that, ceteris paribus, there is a clear relationship between the degree of cohesiveness of multiple principals and agency discretion. Whereas preference heterogeneity between multiple principals is more likely to lead to high agent discretion, preference homogeneity of multiple principals leads to low agent discretion and thus constrains the agent more during FTA negotiations.

A second finding of this study is that, even if multiple principals closely monitor their agent during the negotiation of FTAs in the form of oversight committees, in a situation of disunity within the collective principal, the agent is able to strategically build coalitions with interest groups supporting trade agreements to circumvent the centralized control mechanisms. The Commission additionally buffered by only reporting superficially and holding information back from the principals on the most controversial parts of the FTA, such as the duty drawback and safeguard clauses. Even though the Commission was closely supervised by the Council and the EP at the committee level, its discretion was high 
when negotiating the FTA with South Korea in particular due to the low degree of cohesiveness between multiple principals.

How can these findings be generalized beyond trade? In situations of similarly complex delegation, preference heterogeneity or homogeneity of multiple principals and different types of control mechanisms (police patrol and fire alarms) are likely to lead to similar patterns of discretion. However, further studies are necessary to systematically analyze delegation relationships in other policy areas. For example, the complexity of delegation could be categorized into different stages, namely the representation, negotiation, monitoring and implementation ones. Whether the range of discretion varies in each one of these different stages across policy areas and, if so, why and how in these stages needs to be systematically analyzed in future research.

\section{Notes}

1. This research has received funding from the European Union's Seventh Framework Programme for research, technological development and demonstration under ERC grant agreement no. 312368. Earlier versions of this chapter were presented at EUSA 2015 in Boston and at the Workshop EU as Global Negotiator at the European University Institute 2014 in Florence. I am particularly grateful to Johan Adriaensen, Marise Cremona, Tom Delreux, Andreas Dür, Markus Gastinger, Adrienne Héritier, Paulette Kurzer and Laura Mahrenbach for their very helpful comments.

2. Before the entry into force of the Treaty of Lisbon, the Foreign Affairs Council was called the General Affairs and External Relations Council.

3. So far, the EP has only rejected ACTA, the fisheries agreement with Morocco and the 2010 EU-US SWIFT agreement, arguing its substantive concerns were disregarded by the Commission.

4. Even though the principal-agent literature uses two approximate concepts related to discretion, namely autonomy and agency slack, in this chapter I focus merely on the term discretion. For a discussion on these different concepts, see Bauer et al. (2015) and Heldt (2017).

5. This thesis goes back to the assumption that the EP is more likely to take into account the demands of societal groups civil society and NGOs (Meunier and Nicolaidis 2011). For example, when it came to the negotiation of the EU-Mexico and EU-Australia trade agreements, the EP asked for the inclusion of a democracy clause (Szymanski and Smith 2005). In the latter case, negotiations failed, among other reasons, due to the EU demand that a democracy clause be included in the agreement. 
6. Nicolaïdis and Meunier (2000) and Kerremans (2004) were the first to use these terms in EU trade governance.

7. Before the entry into force of the Treaty of Lisbon, this Committee was called 'the article 113/133 Committee'. For the sake of simplicity, when referring to this committee, I will use the term TPC.

8. However, the ratification process has not been initiated yet, as the Commission requested an opinion of the European Court of Justice on whether the FTA with Singapore falls within the EU's exclusive or shared competence. The EP is also waiting for the opinion of the ECJ before ratifying the agreement.

\section{REFERENCES}

Adriaensen, J. (2016). National administrations in EU trade policy: Maintaining the capacity to control. Palgrave MacMillan: Houndmills.

Agence Europe. (2007, October 12). Seoul makes concessions next week to spur conclusion of FTA.

Agence Europe. (2009a, September 29). Without definite improvement in terms, particularly for cars, ACEA will oppose FTA with South Korea.

Agence Europe. (2009b, March 9). Still no consensus between twenty-seven on FTA.

Agence Europe. (2009c, March 20). ACEA fears unilateral opening of community automotive market to South-Korea.

Agence Europe. (2010, June 23). Parliamentary committee approves safeguard clause in free trade agreement with South Korea.

Agence Europe. (2012, December 17). Free trade negotiations finalised.

Bauer, M., Conceição-Heldt, E., \& Ege, J. (2015). Autonomiekonzeptionen internationaler Organisationen im Vergleich. PVS Sonderheft Internationale Organisationen, 49, 28-53.

Carpenter, D. (2001). The forging of bureaucratic autonomy: Reputations, networks, and policy innovation in executive agencies, 1862-1928. Princeton: Princeton University Press.

Committee on International Trade: European Parliament. (2010). Draft recommendation on the proposal for a council decision concluding the free trade agreement between the European Union and its member states, of the one part and the Republic of Korea, of the other part. Brussels: European Parliament.

Conceição-Heldt, E. (2010). Who controls whom? Dynamics of power delegation and agency losses in EU trade politics. Journal of Common Market Studies, 48(5), 1109-1126.

Conceição-Heldt, E. (2011). Variation in member states' preferences and the Commission's discretion in the Doha round. Journal of European Public Policy, 18(3), 402-418. 
Conceição-Heldt, E. (2013). Do Agents "Run Amok"? Agency slack in the EU and US trade policy in the Doha Round. Journal of Comparative Policy Analysis, 15(1), 21-36.

Conceição-Heldt, E. (2014). When speaking with a single voice isn't enough: Bargaining power (a)symmetry and EU external effectiveness in global trade governance. Journal of European Public Policy, 21(7), 980-995.

Conceição-Heldt, E. (2016, April 14-16). Exploring the paradox of transparency in TTIP negotiations. Paper presented at Council for European Studies, Philadelphia.

Coremans, E., \& Kerremans, B. (2017). Agents as information asymmetry managers in EU trade policy-making. In T. Delreux \& J. Adriaensen (Eds.), The principal-agent model and the European Union (pp. 227-253). London: Palgrave MacMillan.

Delreux, T., \& Kerremans, B. (2010). How agents weaken their principals' incentives to control: The case of EU negotiators and EU member states in multilateral negotiations. Journal of European Integration, 32(4), 357-374.

Delreux, T., \& Adriaensen, J. (2017). Introduction. Use and limitations of the principal-agent model in studying the European Union. In T. Delreux \& J. Adriaensen (Eds.), The principal-agent model and the European Union (pp. 1-34). London: Palgrave MacMillan.

DiMaggio, P., \& Powell, W. (1991). The new institutionalism in organizational analysis. Chicago: Chicago University Press.

Directorate General for External Policies. (2009). The EU-Korea free trade agreement. Brussels: European Parliament.

Dür, A. (2007). EU trade policy as protection for exporters. Journal of Common Market Studies, 45(4), 833-855.

Dür, A., \& Zimmermann, H. (2007). Introduction: The EU in international negotiations. Journal of Common Market Studies, 45(4), 771-787.

Dür, A. (2010). Protection for exporters: Discrimination and liberalization in transatlantic trade relations, 1930-2010. Ithaca, NY: Cornell University Press.

Eeckhout, P. (2011). EU external velations. Oxford: Oxford University Press.

Elsig, M. (2010). European trade policy after enlargement: Larger crowds, shifting priorities and informal decision-making. Journal of European Public Policy, $17(6), 781-798$.

Elsig, M., \& Dupont, C. (2012). European Union meets South Korea: Bureaucratic interests, exporter discrimination and the negotiations of trade agreements. Journal of Common Market Studies, 50(3), 492-507.

Elsig, M. (2013). The EU as an effective trade power? Strategic choice of judicial candidates in the context of the World Trade Organization. International Relations, 27(3), 325-340.

Epstein, D., \& O'Halloran, S. (1999). Delegating powers. A transaction cost politics approach to policy making under separate powers. Cambridge: Cambridge University Press. 
Commission, European. (2010). Proposal for a council decision concluding the free trade agreement between the European Union and its member states and the Republic of Korea. Brussels: European Commission.

European Commission Department of Trade. (2015). Countries and Regions: Singapore. Retrieved November 2015, from http://ec.europa.eu/trade/policy/countries-and-regions/countries/singapore/.

Frieden, J. (1999). Actors and preferences in international relations. In D. Lake \& R. Powell (Eds.), Strategic choice and international relations (pp. 39-76). Princeton: Princeton University Press.

Goldstein, J. (2012). Trade liberalization and domestic politics. In A. Narlikar, M. Daunton, \& R. Stern (Eds.), The Oxford handbook on the World Trade Organization (pp. 64-82). Oxford: Oxford University Press.

Hawkins, D., \& Jacoby, W. (2006). How agents matter. In D. Hawkins, D. Lake, D. Nielson, \& M. Tierney (Eds.), Delegation and agency in international organizations (pp. 199-228). Cambridge: Cambridge University Press.

Hawkins, D., Lake, D., Nielson, D., \& Tierney, M. (Eds.). (2006a). Delegation and agency in international organizations. Cambridge: Cambridge University Press.

Hawkins, D., Lake, D., Nielson, D., \& Tierney, M. (2006b). Delegation under anarchy: States, international organizations, and principal-agent theory. In D. Hawkins, D. Lake, D. Nielson, \& M. Tierney (Eds.), Delegation and agency in international organizations (pp. 3-38). Cambridge: Cambridge University Press.

Heldt, E. (2017). Regaining control of errant agents: Agency slack at the European Commission and the World Health Organization. Cooperation and Conflict. doi: $10.1177 / 0010836717703673$.

Helwig, N. (2017). Agent interaction as a source of discretion for the EU High Representative. In T. Delreux \& J. Adriaensen (Eds.), The principal-agent model and the European Union (pp. 105-129). London: Palgrave MacMillan.

Kerremans, B. (2004). Principal(s) versus agent: An analysis of the impact of member states' control on the commission's behaviour as trade policy entrepreneur in WTO negotiations. IIEB Working Paper 3.

Kiewiet, D., \& McCubbins, M. (1991). The logic of delegation: Congressional parties and the appropriations process. Chicago, IL: University of Chicago Press.

Krajewski, M. (2013). New functions and new power for the European Parliament: Assessing the changes of the common commercial policy from the perspective of democratic legitimacy. In M. Bungenberg \& C. Herrmann (Eds.), European yearbook of international economic law: Special issue: Common commercial policy after Lisbon (pp. 67-86). Berlin: Springer.

Kroll, D. A. (2017). Manifest and latent control on the council by the European Council. In T. Delreux \& J. Adriaensen (Eds.), The principal-agent model and the European Union (pp. 157-180). London: Palgrave MacMillan. 
Lupia, A. (2003). Delegation and its Perils. In K. Strom, W. Müller, \& T. Bergman (Eds.), Delegation and accountability in parliamentary democracies (pp. 33-54). Oxford: Oxford University Press.

McCubbins, M., \& Schwartz, T. (1984). Congressional oversight overlooked: Police patrols versus fire alarms. American Journal of Political Science, 28(1), 165-179.

McCubbins, M., Noll, R., \& Weingast, B. (1987). Administrative procedures as instruments of political control. Journal of Law Economics, \& Organization, $3(2), 243-277$.

McCubbins, M., \& Page, T. (1987). A theory of congressional delegation. In M. McCubbins \& T. Sullivan (Eds.), Congress: Structure and policy (pp. 409425). New York: Cambridge University Press.

Meunier, S., \& Nicolaïdis, K. (2000). EU trade policy: The exclusive versus shared competence debate. In Cowles M. Green \& M. Smith (Eds.), The state of the European Union (pp. 325-346). Oxford: Oxford University Press.

Meunier, S. (2003). Trade policy and political legitimacy in the European Union. Comparative European Politics, 1(1), 67-90.

Meunier, S., \& Nicolaidis, K. (2011). The European Union as a trade power. In C. Hill \& M. Smith (Eds.), International relations and the European Union (pp. 275-298). Oxford: Oxford University Press.

Milner, H. (1997). Interests, institutions, and information: Domestic politics and international relations. Princeton, NJ: Princeton University Press.

Moe, T. (1990). Political institutions: The neglected side of the story. Journal of Law, Economics, \& Organization, 6(1), 213-253.

Moravcsik, A. (1993). Preferences and power in the European community: A liberal intergovernmentalist approach. Journal of Common Market Studies, 31(4), 473-524.

Moravcsik, A. (1997). Taking preferences seriously: A liberal theory of international politics. International Organization, 51(4), 513-553.

Nielson, D., \& Tierney, M. (2003). Delegation to international organizations: Agency theory and World Bank Environmental reform. International Organization, 57(2), 241-276.

Niemann, A., \& Huigens, J. (2011). The European Union's role in the G8: A principal-agent perspective. Journal of European Public Policy, 18(3), 420-442.

Niemann, A., \& Bretherton, C. (2013). EU external policy at the crossroads: The challenge of actorness and effectiveness. International Relations, 27(3), 261-275.

Plank, F., \& Niemann, A. (2017). Impact of the agent's environment on discretion in the field of EU conflict resolution. In T. Delreux \& J. Adriaensen (Eds.), The principal-agent model and the European Union (pp. 131-155). London: Palgrave MacMillan.

Pollack, M. (1997). Delegation, agency, and agenda setting in the European Community. International Organization, 51(1), 99-134. 
Pollack, M. (2003). The engines of European integration: Delegation, agency, and agenda setting in the EU. Oxford: Oxford University Press.

Putnam, R. (1988). Diplomacy and domestic politics: The logic of two-level games. International Organization, 42(3), 427-460.

Richardson, L. (2012). The post-Lisbon role of the European Parliament in the EU's common commercial policy: Implications for bilateral trade negotiations (p. 5). EU Diplomacy Papers: College of Europe.

Szymanski, M., \& Smith, M. (2005). Coherence and conditionality in European foreign policy: Negotiating the EU-Mexico global agreement. Journal of Common Market Studies, 43(1), 171-192.

Tallberg, J. (2000). The anatomy of autonomy: An institutional account of variation in supranational influence. Journal of Common Market Studies, 38(5), 843-864.

Tallberg, J., Sommerer, T., Squatrito, T., \& Jönsson, C. (2013). Opening Up: International organizations and transnational actors. Cambridge: Cambridge University Press.

Thatcher, M., \& Stone, Sweet A. (2002). Theory and practice of delegation to non-majoritarian institutions. West European Politics, 25(1), 1-22.

Van den Putte, L., De Ville, F., \& Orbie, J. (2015). The European Parliament as an international actor in trade: From power to impact. In S. Stavridis \& D. Irrera (Eds.), The European Parliament and its international relations (pp. 52-69). Abingdon: Routledge.

Votewatch Europe. (2014). Free trade agreement between the EU and the Republic of Korea. Retrieved June 2014, from http://www.votewatch.eu/ en/free-trade-agreement-between-the-eu-and-the-republic-on-korea-draftlegislative-resolution-recommend.html-/\#\#vote-tabs-list-2.

Whitford, A. (2005). The pursuit of political control by multiple principals. The Journal of Politics, 67(1), 29-49.

Woolcock, S. (2010). The treaty of Lisbon and the European Union as an actor in international trade. ECIPE Working Paper. Brussels.

\section{Author Biography}

Eugénia da Conceição-Heldt holds the chair of European and Global Governance at the Bavarian School of Public Policy, TUM School of Governance, Technical University of Munich. Her work focuses on the delegation of power to international organizations, EU trade politics, negotiation analysis, and emerging powers. She has published articles on these topics in journals such as the Journal of Common Market Studies, the Journal of European Public Policy, International Politics, Global Policy, and Cooperation and Conflict. 
Open Access This chapter is licensed under the terms of the Creative Commons Attribution 4.0 International License (http://creativecommons.org/licenses/ by $/ 4.0 /$ ), which permits use, sharing, adaptation, distribution and reproduction in any medium or format, as long as you give appropriate credit to the original author(s) and the source, provide a link to the Creative Commons license and indicate if changes were made.

The images or other third party material in this chapter are included in the chapter's Creative Commons license, unless indicated otherwise in a credit line to the material. If material is not included in the chapter's Creative Commons license and your intended use is not permitted by statutory regulation or exceeds the permitted use, you will need to obtain permission directly from the copyright holder.

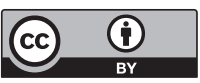

